\title{
Production of Electricity from Flared Associated Gas as a Strategy for Reduction of Environmental Pollutions in Oil and Gas Sector (A Case Study of Niger Delta)
}

\author{
Mathew Chidube Udechukwu, Ubanozie Julian Obibuike, Anthony Chemazu Igbojionu, \\ Stanley Toochukwu Ekwueme*
}

Department of Petroleum Engineering, Federal University of Technology, Owerri (FUTO), Nigeria

Email address:

stanleyekwueme@yahoo.com (S. T. Ekwueme)

*Corresponding author

\section{To cite this article:}

Mathew Chidube Udechukwu, Ubanozie Julian Obibuike, Anthony Chemazu Igbojionu, Stanley Toochukwu Ekwueme. Production of Electricity from Flared Associated Gas as a Strategy for Reduction of Environmental Pollutions in Oil and Gas Sector (A Case Study of Niger Delta). International Journal of Oil, Gas and Coal Engineering. Vol. 8, No. 3, 2020, pp. 68-74. doi: 10.11648/j.ogce.20200803.13

Received: February 28, 2020; Accepted: June 28, 2020; Published: July 13, 2020

\begin{abstract}
The flaring of associated gas has become a global challenge. Aside the financial implication resulting from associated gas flaring, the environmental consequences are enormous and poses great threats to humans and the underlying ecosystem. The environmental implication is the degradation of the ecosystem resulting to loss of ecological lives, emergence of sicknesses, air, water and land pollution, release of poisonous gases that hamper human habitation, release of greenhouse gases resulting to global warming, severe respiratory diseases like asthma, bronchitis have been linked to flaring of associated gas in the host communities. The goal of the world health organization to completely eradicate gas flaring by 2030 has forced many countries to make laws that favour the utilization of associated gas and the further development of gas projects. Costly gas projects have undergone technological improvement, miniaturization and scaling to become portable and profitable ventures. In this paper, we propose means of utilising and monetising the flared associated gas in generation of electricity by a method known as gas-to-wire, this is the process of generating electricity from natural gas at or near the proximity of the field. The produced electricity is supplied to nearby host communities while surplus is supplied to the main electricity grid. Izombe production sites have been taken for case study. The turbine system used is a combined cycle gas turbine with a daily gas feedrate of 40MMscfd. The technical and economic parametres relative to the project are analyzed and discussed. The project promises a potential solution to the Nigeria electricity problem by diversification of electricity production and distribution and reduction in over-reliance on national grid.
\end{abstract}

Keywords: Gas Flaring, Power Generation, Pollution Reduction, Gas-to-wire

\section{Introduction}

Nigeria has a proven gas reserve of 199 trillion cubic feet, ranking in the top ten in the world. A significant volume of associated gas, produced with crude oil is currently being flared. Nigeria flared an estimated 289 billion standard cubic feet of gas in 2016, making her one of the top ten gas flaring nations in the world (Nigeria Gas Flare Commercialization Programme [1]. Approximately 790 million standard cubic feet per day (MMscfd) of natural gas associated with petroleum production is being flared from approximately 180 flare sites within Nigeria's oil and gas fields today. Gas flaring has resulted to many consequences especially in Nigeria. Aside the billions of dollars lost annually to gas flaring when quantified financially, a lot of other impacts of gas flaring is noticeable $[2,3]$. The severe environmental degradation of the ecosystem resulting to loss of ecological lives, emergence of sicknesses, air, water and land pollution, release of poisonous gases that hamper human habitation, release of greenhouse gases resulting to global warming to mention but a few $[4,5]$. With all these, the Niger Delta of Nigeria can be said to be the area most impacted by oil activities in the world. 


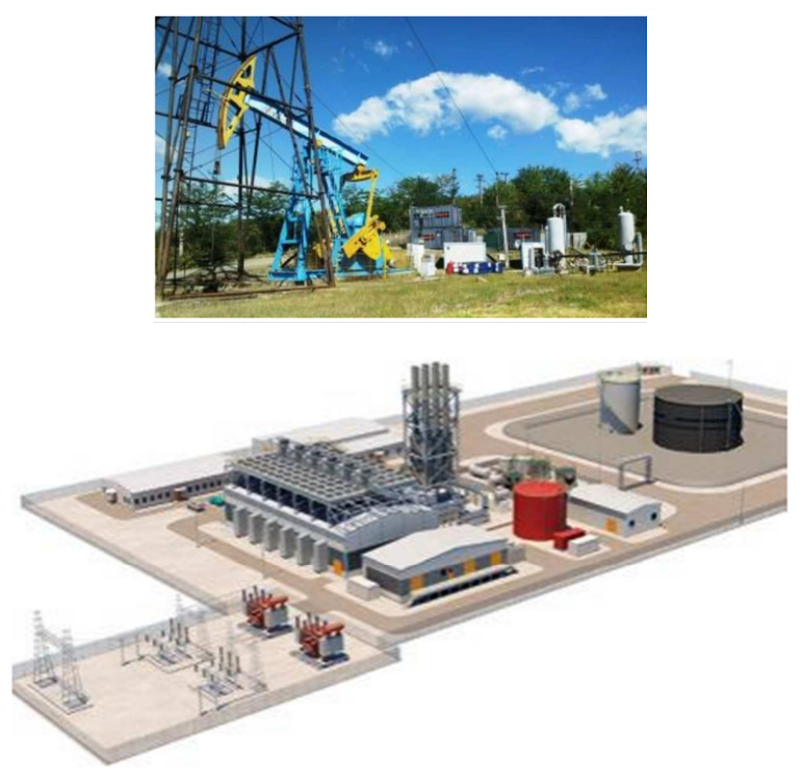

(Source: Global Gas flaring Reduction Partnership [9]

Figure 1. a. Gas-to-wire installation onsite; $b$. Gas-to-wire onsite design.

Nigeria with its vast natural gas reserve has only reached a peak power generation of 5074MW for more than 190Million heads of population making it $26.7 \mathrm{MW}$ per million heads of population [6]. The only way to solve the problem of power in Nigeria lies in the efficient utilization of the associated gas in the country. Much of the electricity generation in the country have taken the route of big turbine systems being supplied gas by large pipeline networks [7]. These have been the scenario in the gas generation systems in Nigeria of which the Afam power plant is a major example. This method of power generation that utilizes large turbines have performed below capacity. The poor performance of the large power plants was fuelled by the instabilities in the Nigeria political system which affected both the gas sector and the power sector. For this reason, a new method of power generation that is not affected by political instabilities will go a long way in addressing the Nigeria power problems and this can only be met by independent power generators of which associated flare gas holds great potentials [8]. Gas-towire technologies provides onsite electricity by utilising associated natural gas in gas turbine plants.

This technology holds great potentials for the vast associated gases scattered at various remote locations in the Niger Delta. In most cases, the gas-to-wire technologies are operated in small or mini scales. These technologies are modularized to enable easy handling, and movements from one place to another. Modularizing the gas turbine systems offers economic and technical advantages that opens windows for private and independent investors.

\section{Gas-to-Wire Turbine Systems - Combined Cycle Gas turbine}

Gas fired turbine systems are utilized in gas-to-wire technologies in production of electricity. The turbine systems are of two types: the single gas turbine and the combined cycle gas turbine $[10,11]$. A combined-cycle power plant uses both gas and steam turbines together to produce more electricity from the same fuel than a traditional single-cycle plants [12]. The waste heat from the gas turbine is routed to the nearby steam turbine, which generates extra electrical power [13]. A Combined Cycle Power Plant produces high power outputs at high efficiencies (up to 60\%) and with low emissions. A Conventional power plant has efficiency of about $33 \%$ electricity only and remaining $67 \%$ as waste [14-16].

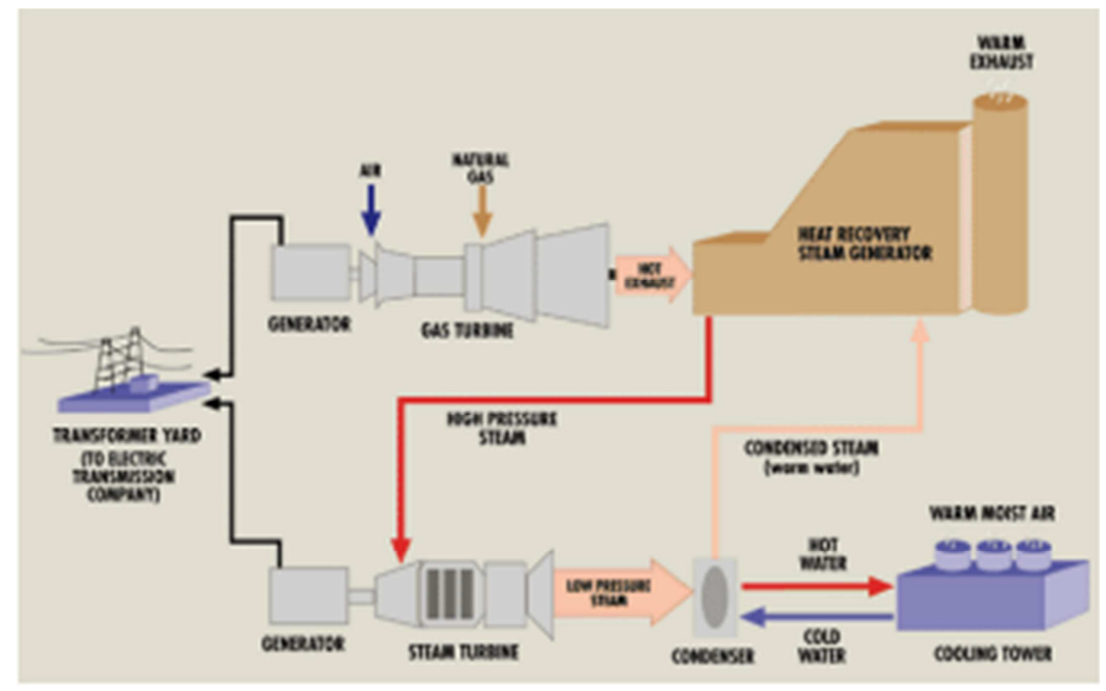

Figure 2. The schematic diagram of combined cycle gas turbine power plant. (Osaghae et al, 2004).

\section{Methodology}

The method comprises the process for power generation using the gas-to-wire technology, the description of the technical and economic performance of the technology.

\subsection{Processes Involved in Gas-to-Power Plant Systems}

To use associated flare gas from flare lines for power 
generation via gas-to-wire technology, the following steps are encountered

1. Pre-treatment of the flare gas

2. Separation of hydrocarbon liquids via NGL recovery mechanisms

3. Conversion of the resulting dry gas to electricity via combine cycle gas turbine system

4. Distribution of the produced power to usage areas

The pre-treatment removes impurities from the natural or reduce them to acceptable levels to be fed to the gas turbine. Power generation principles stipulates that the gas be free from impurities such as $\mathrm{H}_{2} \mathrm{~S}, \mathrm{CO}_{2}$ and sulphur components. $\mathrm{H}_{2} \mathrm{~S}$ and $\mathrm{CO}_{2}$ are called acid gases and constitute operational difficulties in the turbine system such as corrosion of mechanical parts. These gases must be removed and the resulting methane or dry gas must be of high purity as feed stream for the turbine system. After the pretreatment of the feed flare gas, the next is to recover the liquid portion of the gas. This stage is dependent on the initial composition of the feed gas. Some gas contain appreciable portions of the liquid ends called natural gas liquids that is composed of ethane plus hydrocarbons. If the flare gas has appreciable mole percent of ethane plus components, then it may be required to extract this components after the treatment of the gas. These ends are sold as NGLs or a mixed to produce more petrochemical products. Of the notable ends derived from NGLs is the liquefied petroleum gas which is compose of propane and butane.

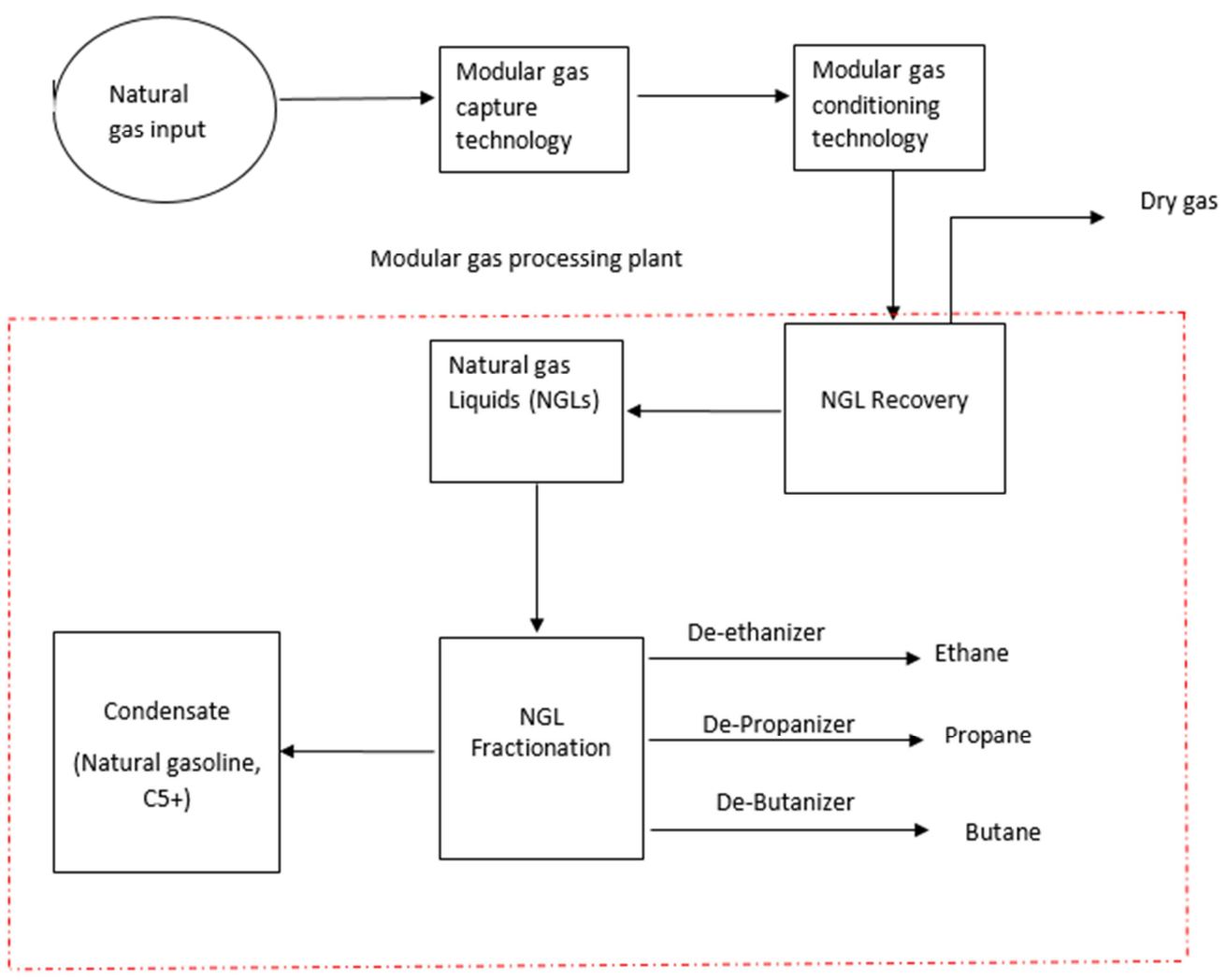

Figure 3. Process schematics of the several stages in the gas-to-wire project.

The mole composition of the flare natural gas before the pre-treatment and processing are given below.

Table 1. Mole composition of raw flare natural gas from Izombe in the Niger Delta.

\begin{tabular}{ll}
\hline Component & Mole\% \\
\hline Methane & 79.59 \\
Ethane & 8.76 \\
Propane & 6.63 \\
Iso-butane & 1.16 \\
N-butane & 1.3 \\
Iso-pentane & 0.54 \\
N-pentane & 0.63 \\
Hexane plus & 0.27 \\
Carbondioxide & 0.75 \\
Nitrogen & 0.37 \\
Total & 100 \\
\hline
\end{tabular}

\subsection{The Turbine Processes and Performance Systems}

In this part, we describe the processes in the production of electricity using the pre-treated and processed associated flare gas and the indices for the technical evaluation of the turbine system.

1. Heat Rate: The heat rate is the amount of energy used by an electrical generator or power plant to generate one kilowatt hour ( $\mathrm{kWh}$ ) of electricity and is typically expressed as GJ/GWh.

$$
\text { Heat rate }=\frac{\text { thermal energy in }}{\text { electrical energy out }}
$$

$1 \mathrm{kwh}=3.6 \mathrm{mj}=3412 \mathrm{Btu} ; 1 \mathrm{mwh}=3600 \mathrm{mj}$

2. Heat Content: Heat content is the amount of heat energy 
available to be released by the transformation or use of a specified physical unit of an energy form

3. Fuel usage: This is the volume of natural gas needed to produce $1 \mathrm{kwh}$ of electricity. The fuel usage varies for different turbine and fuels used. It is also affected by the efficiency of the plant

Kilowatt hour generated per unit of fuel used $=$ Fuel heat content (in Btu per physical unit) / Heat rate (in Btu per $\mathrm{kWh})$.

\subsection{Technical Parametres}

The input parametres for the natural gas and turbine system used in this work is given below

Table 2. Table of Input values of natural gas and turbine properties.

\begin{tabular}{ll}
\hline Parameter & Value \\
\hline Heat content of natural gas & 1029 Btu/scf \\
Turbine efficiency & $60 \%$ \\
Natural gas flowrate & $40 \mathrm{MMscfd}$ \\
\hline
\end{tabular}

\section{Results and Discussions}

The results for the gas-to-wire processes are given below.

\subsection{Liquid Recovery from Processing}

The NGL recovery statistics for the liquid recovery in the processing unit is summarized in the table below. These hydrocarbon liquids are sold and additional revenue is recovered for the operators. If the operators are responsible for the electricity generation, then the revenue accrued from the sale of NGL will be added to the revenue from the sales of electrical power to consumers.

Table 3. NGL Recovery Volume statistics.

\begin{tabular}{|c|c|c|c|c|c|c|c|c|c|}
\hline \multirow[b]{2}{*}{ Component } & \multirow{2}{*}{$\begin{array}{l}\text { Mole } \\
\text { Percent }\end{array}$} & \multirow[b]{2}{*}{ Gal/Mol } & \multirow[b]{2}{*}{ GPM } & \multicolumn{2}{|c|}{ AVALAIBLE } & \multirow{2}{*}{$\begin{array}{l}\text { Net } \\
\text { Recovered } \\
\text { Liquids Gal/d }\end{array}$} & \multirow{2}{*}{$\begin{array}{l}\text { Net Recovered } \\
\text { Liquids Bbls/d }\end{array}$} & \multirow{2}{*}{$\begin{array}{l}\text { Residue Gas } \\
\text { Vol Mmscfd }\end{array}$} & \multirow{2}{*}{$\begin{array}{l}\text { Residue Gas } \\
\text { Mole\% }\end{array}$} \\
\hline & & & & Gal/Day & $\begin{array}{l}\text { Estimated } \\
\text { Recovery }\end{array}$ & & & & \\
\hline Nitrogen & 0.37 & & & & 0 & & & 0.148 & 0.452406 \\
\hline Carbondioxide & 0.75 & & & & 0 & & & 0.3 & 0.91704 \\
\hline Methane & 79.59 & 6.417 & & & 0 & & & 31.836 & 97.31625 \\
\hline Ethane & 8.76 & 10.123 & 2.336803 & 93472.13 & 90 & 84124.92 & 2002.974 & 0.3504 & 1.071102 \\
\hline Iso-butane & 1.16 & 12.386 & 0.378615 & 15144.6 & 100 & 15144.6 & 360.5858 & 0 & 0 \\
\hline N-butane & 1.3 & 11.933 & 0.408791 & 16351.66 & 100 & 16351.66 & 389.3252 & 0 & 0 \\
\hline Iso-pentane & 0.54 & 13.855 & 0.197156 & 7886.224 & 100 & 7886.224 & 187.7672 & 0 & 0 \\
\hline $\mathrm{N}$-pentane & 0.63 & 13.712 & 0.227641 & 9105.633 & 100 & 9105.633 & 216.8008 & 0 & 0 \\
\hline Hexane plus & 0.27 & 15.566 & 0.110751 & 4430.06 & 100 & 4430.06 & 105.4776 & 0 & 0 \\
\hline TOTAL & 100 & & & & & 207732.6 & 4946.015 & 32.71396 & 100 \\
\hline INLET GAS & $\begin{array}{l}\text { 40MMS } \\
\text { CFD }\end{array}$ & & & & & & & & \\
\hline
\end{tabular}

From table 3 above, the total volume of NGL recovered from 40 MMscfd of raw flare natural gas is $4946 \mathrm{~b} / \mathrm{d}$. The resulting volume of dry gas after NGL recovery is $32.7 \mathrm{MMscfd}$. This is the volume fed to the turbine system for power generation.

\subsection{Results for Turbine Power Generation}

From the parametres given

$$
\text { Heat content of natural gas }=1029 \mathrm{btu} / \mathrm{scf}
$$

Kilowatt-hour generated per unit of fuel used $=1029 / 3412=0.301583 \mathrm{kwh} / \mathrm{scf}$

Daily allowable energy generated $=$ Feedrate $($ MMscfd $) * 0.301583 \mathrm{kwh} / \mathrm{scf}$

For 32.7MMscfd

$$
\text { Daily energy generated }(\mathrm{kWh})=\left(32.7 * 10^{\wedge} 6\right) * 0.301583 \mathrm{kWh} / \mathrm{scf}=9650645 \mathrm{kWh}
$$

Since the turbine works for $24 \mathrm{hrs}$ period a day, the electrical power generated in megawatts by a CCGT gas turbine with efficiency of $60 \%$ is given by

$$
\text { Electrical Power generated }=\frac{9650645}{24} * \frac{1}{1000} * \frac{60}{100}=243 \mathrm{MW}
$$


The electrical energy generated for $32.7 \mathrm{MMscfd}$ of treated dry gas is $243 \mathrm{MW}$. Table 4 below shows the energy generated for different volume of treated natural gas feed stream.

Table 4. Gas energy and Power outputs of natural gas streams.

\begin{tabular}{lll}
\hline Volume of Turbine feed gas MMscfd & Energy generated (kWh) & Power generated (MW) \\
\hline 20 & 1977400 & 151 \\
32.7 & 3233049 & 243 \\
60 & 5932200 & 452 \\
80 & 7909600 & 603 \\
100 & 9887000 & 754 \\
\hline
\end{tabular}

Figure 4 below shows the relationship between natural gas volume and power generated.

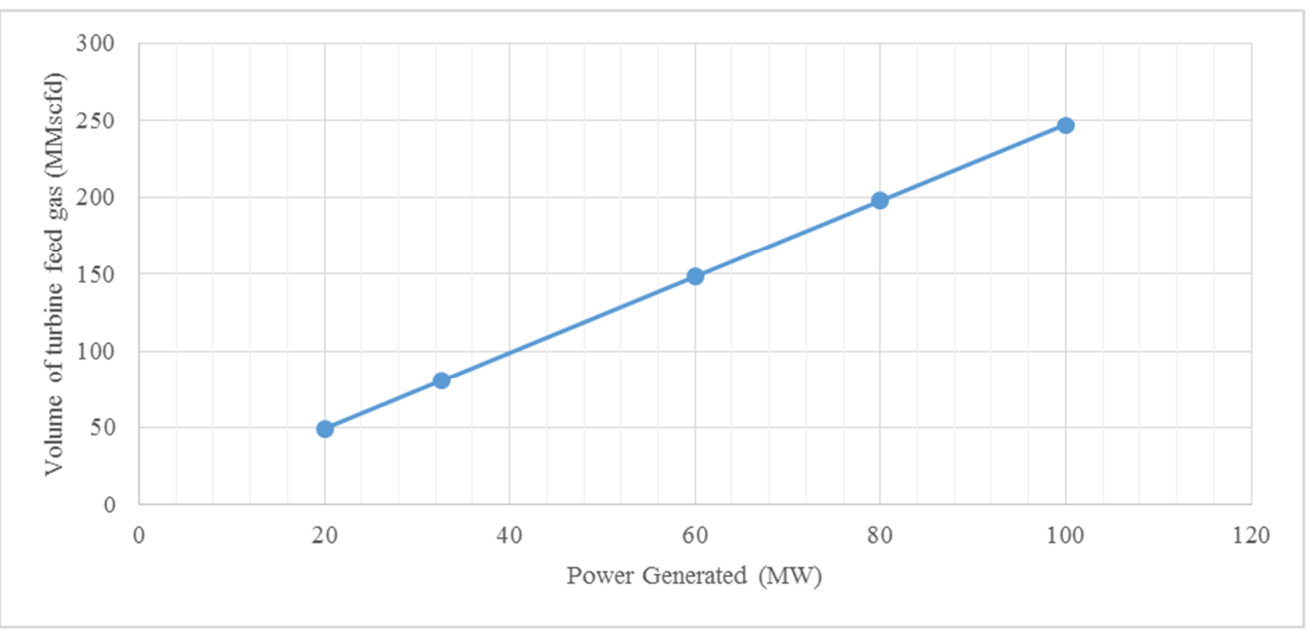

Figure 4. Relationship between natural gas volume and power generated.

\subsection{Power Usage Calculation}

If the electrical energy generated is to be wholly sold or supplied to host communities, it is pertinent to ascertain the number of households or individuals that the electrical energy will be sufficient to meet. For this reason we calculate the electrical energy requirement of each household. For equipment ratings, check the label of equipment and record their values accordingly, otherwise check with local appliance dealers or product manufacturers for information.

Table 5. Power Ratings for a Typical Rural Home Appliances.

\begin{tabular}{llllll}
\hline Appliance & Consumption (watts) & Number & Total wattage & hrs./day & Watt-hrs./day \\
\hline Energy bulbs & 10 & 12 & 120 & 12 & 1440 \\
DVD & 40 & 3 & 120 & 6 & 720 \\
Television & 50 & 4 & 200 & 8 & 1600 \\
Mobile phones & 5 & 6 & 30 & 10 & 300 \\
Ceiling fan & 25 & 8 & 200 & 10 & 2000 \\
Radio cassette player & 8 & 2 & 16 & 5 & 80 \\
Total & & & & & 6140 \\
\hline
\end{tabular}

From the table above, each household requires an average power requirement of 6140 watt-hr per day. Table 6 below shows the relationship between energy produced and number of households the energy will be sufficient for.

Table 6. Table showing Power requirement and number of households.

\begin{tabular}{llll}
\hline Natural gas volume & Power generated & Energy generated & No. of households required \\
\hline 20 & 3618996 & 151 & 589 \\
32.7 & 5826584 & 243 & 949 \\
60 & 10856988 & 452 & 1768 \\
80 & 14475984 & 603 & 2358 \\
100 & 18094980 & 754 & 2947 \\
\hline
\end{tabular}

From table 6 above, the power generated for our case study will be sufficient for 949 households using an average power of 6140 watt-hrs per day. Figure 5 below gives the graphical relationship between electrical energy produced and power generated. 


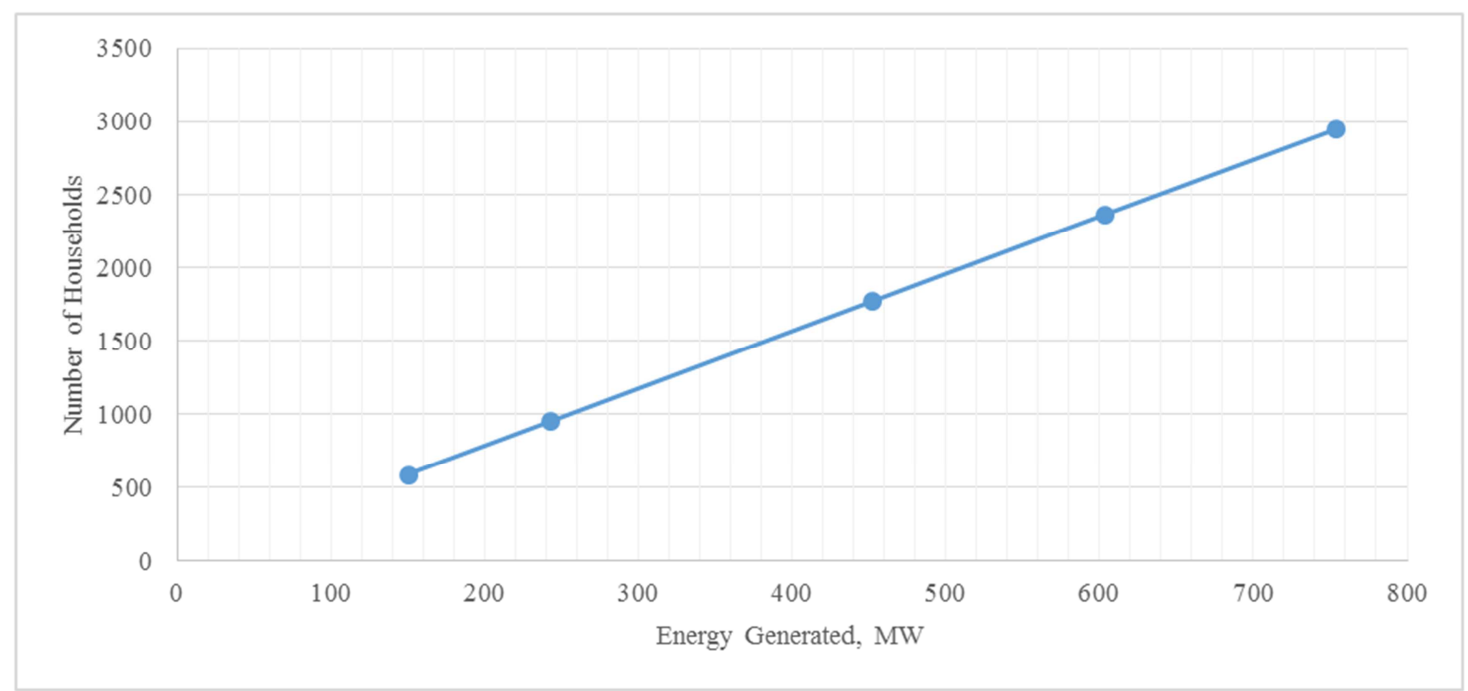

Figure 5. Relationship between Number of households using electricity and power generated.

\subsection{Economic Evaluation Results}

The economic evaluation of the gas-to-wire technology is done to ascertain economic appraisal parametres like NPV, POT, DCF-ROR and P/\$. The capital expenditure (CAPEX) for the plant is US\$250 million while the operating expenditure is $5 \%$ of the CAPEX. The operating expenditure comprises the feedstock (natural gas cost) and the nonfeedstock cost. The price of the power generated when sold is given as US0.08/kWh. A tax rate of $35 \%$ and 350 days of plant operation for a plant life of 20 years is considered. The result for the economic evaluation of the gas-to-power project is given in table 7 below.
Table 7. Table of Profit Indicators of the Gas-to-wire Project.

\begin{tabular}{ll}
\hline Economic Parameter & Value \\
\hline Annual Cashflow/NCR (US\$) & $102,293,829$ \\
NPV @ 10\% Discount Rate (US\$) & 620885030 \\
NPV @ 15\% Discount Rate (US\$) & 390290982 \\
DCF-ROR (\%) & 41 \\
Pay-Out Time, POT (yrs) & 2.44 \\
P/\$ & 7.2 \\
\hline
\end{tabular}

From table 7 above, the NPV of the project at $10 \%$ and $15 \%$ discount rates are US\$620885030 and US $\$ 390290982$ respectively, the DCF-ROR is $41 \%$ while the pay-out time is 2.44 years. The profit-per-investment ratio is 7.2 . These values show that the project is highly economically viable.

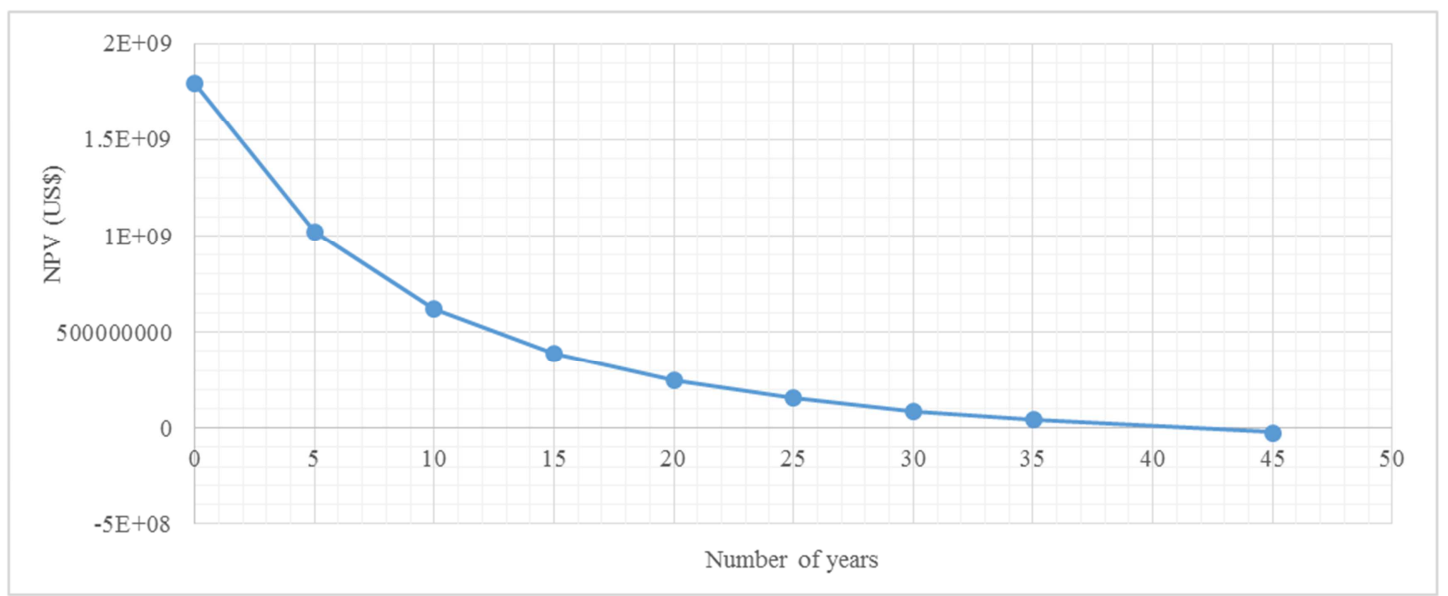

Figure 6. Figure showing the Relationship between the NPV and Discount rates.

From figure 6 , the curve cut the $\mathrm{x}$-axis at $41 \%$, this point is the DCF-ROR. This means that the project is profitable as long as the discount rate is below $41 \%$.

\section{Conclusions}

Method for flare gas monetisation using gas-to-wire technology has been evaluated. This method was a means to eradicate gas flaring in the Niger Delta region by utilising flare associated gas for onsite power generation for self-use by the operators and for sale and/or distribution to host communities. The results reveal that for $40 \mathrm{MMscfd}$ of flare gas, $4946 \mathrm{~b} / \mathrm{d}$ of NGL was recovered and the 32.7 MMscfd of remaining dry gas produced $243 \mathrm{MW}$ of electricity using 
combine cycle gas turbine sufficient for 949 individuals/household with a daily average power usage of $6.14 \mathrm{kWh}$. The economic evaluation reveals an NPV of US\$620885030 and US\$390290982 for discount rates of $10 \%$ and $15 \%$ respectively; the DCF-ROR and the Pay-out time are $41 \%$ is 2.44 years. The profit-per-investment ratio is 7.2 making the project an economically viable venture recommended for private investors participation and governmental deployment in the Niger Delta not only as a means of controlling the pollutive effect of gas flaring but also for creating employment and attracting revenue.

\section{Nomenclature}

Btu - British Thermal Units

DCF-ROR - Discounted Cashflow Rate of Return

GPM - Gallon per Thousand

Gwh - Gigawatts Hour

Kwh - Kilowatts Hour

$\mathrm{Mj}$ - Megajoules

MMscf - Million Standard Cubic Feet

Mscf - Thousand Standard Cubic Feet

MW - Megawatts

NCR - Net Cash Recovery

NGFCP - Nigeria Gas Flare Commercialization

Programme

NGL - Natural Gas Liquids

NPV - Net Present Value

POT - Pay-Out Time

$\mathrm{P} / \$$ - Profit per Dollar Invested

\section{References}

[1] Nigeria Gas Flare Commercialization Programme. (2018). Request for Qualification. Nigeria: Ministry of Petroleum and natural resources, Nigeria.

[2] Odumugbo, C. A. (2010). Natural gas utilization in Nigeria: challenges and opportunities, J. Nat. Gas Sci. Eng. 2 310-316.

[3] Anyadiegwu C. I. C, Anyanwu E. E and Obah B. (2012). Economic viability of underground natural gas storage in depleted oil reservoirs in Nigeria. Archives of Applied Science Research, 4 (4): 1880-1893.

[4] Kareem, S. D., F. Kari, G. M. Alam, A. Adewale and Oke (2012). Energy consumption, pollutant emissions and economic growth: China experience. Int. J. Applied Econ.
[5] Ojijiagwo, E., Oduoza, C., Emekwuru, N. (2016). Economics of gas to wire technology applied in gas flare management. UK: Elsevier.

[6] Onwuka, E. I, Iledare, O. O, Echendu, J. C (2016). Gas-toPower in Nigeria: The burden on natural gas. Paper presented at the SPE Nigeria annual international conference and exhibition Lagos, Nigeria.

[7] Aliyu, A. S, Ramli, T. R, Saleh, A. S. (2013). Nigeria electricity crisis: power generation capacity expansion and environmental ramifications, Energy 61 354-367.

[8] Eluagu, R. C, Anyadiegwu, C. I. C, Obah, B. O. (2018). Evaluation of Performance Optimization of Modular Gas Turbine System for Monetisation of Associated Stranded Gas in the Niger Delta. International Journal of Engineering Sciences \& Research Technology.

[9] Global Gas flaring Reduction Partnership (2018). GGFR Technology Overview - Utilization of Small-Scale Associated Gas.

[10] Adaramola MS, Oyewola OM, Paul SS. (2012). Technical and economic assessment of hybrid energy systems in South-West Nigeria. Energy Exploration Exploit; 30 (4): 533-52.

[11] Al-Ibrahim, M. A, Varnham A. (2010) A review of inlet aircooling technologies for enhancing the performance of combustion turbines in Saudi Arabia. Applied Thermodynamics Engineering; 30: 1879-88.

[12] Gujba H, Mulugetta Y, Azapagic A. (2010). Environmental and economic appraisal of power generation capacity expansion plan in Nigeria. Energy Policy; 38: 5636-52.

[13] Farzaneh-Gord M, Deymi-Dashtebayaz M. (2011) Effect of various inlet air cooling methods on gas turbine performance. Energy; 36: 1196-205.

[14] Rahimpour, M. R. Z. Jamshidnejad, S. M. Jokar, G. Karimi, A. Ghorbani, A. H. Mohammadi, A comparative study of three methods for flare gas recovery of Asalooye gas refinery, J. Nat. Gas Sci. Eng. 4 (2012) 17-28.

[15] Kaviri AG, Jaafar MN, Mat Lazim T. (2012). Modeling and multi-objective exergy based optimization of a combined cycle power plant using a genetic algorithm. Energy Convers Manage; 58: 94-103.

[16] Osaghae E. O, Khan J. A, Roa, J. J. (2004). Gas field monetisation: Major investment Drivers for Gas to Power ventures, Paper prepared for presentation at the SPE Asia Pacific Oil and Gas conference and exhibition held in Perth Australia. 